\title{
Extending framework based on the linear coordination polymers: Alternative chains containing lanthanum ion and acrylic acid ligand
}

\author{
Hui Li ${ }^{\mathrm{a}, \mathrm{b}, \mathrm{c}, *}$, Ming Guo ${ }^{\mathrm{a}}$, Hong Tian ${ }^{\mathrm{a}}$, Fei-Yue He ${ }^{\mathrm{a}}$, Gene-Hsiang Lee ${ }^{\mathrm{b}}$, Shie-Ming Peng ${ }^{\mathrm{b}, \mathrm{c}}$ \\ ${ }^{a}$ Department of Chemistry, Beijing Institute of Technology, Beijing 100081, PR China \\ ${ }^{\mathrm{b}}$ Department of Chemistry, National Taiwan University, Taipei, Taiwan 106, ROC \\ ${ }^{\mathrm{c}}$ Institute of Chemistry, Academia Sinica, Taipei, Taiwan 115, ROC
}

Received 2 February 2006; received in revised form 24 June 2006; accepted 17 July 2006

Available online 26 July 2006

\begin{abstract}
One-dimensional alternative chains of two lanthanum complexes: $\left[\mathrm{La}\left(L^{1}\right)_{3}\left(\mathrm{CH}_{3} \mathrm{OH}\right)\left(\mathrm{H}_{2} \mathrm{O}\right)_{2}\right] \cdot 5 \mathrm{H}_{2} \mathrm{O}\left(L^{1}=\right.$ anion of $\alpha$-cyano-4hydroxycinnamic acid ) 1 and $\left[\mathrm{La}\left(L^{2}\right)_{3}\left(\mathrm{H}_{2} \mathrm{O}\right)_{2}\right] \cdot 3 \mathrm{H}_{2} \mathrm{O}\left(L^{2}=\right.$ anion of trans-3-(4-methyl-benzoyl)-acrylic acid) 2 were synthesized and structurally characterized by single-crystal $\mathrm{X}$-ray diffraction, element analysis, IR and thermogravimetric analysis. The crystal structure data are as follows for 1: $\mathrm{C}_{31} \mathrm{H}_{36} \mathrm{LaN}_{3} \mathrm{O}_{17}$, triclinic, $P-1, a=9.8279(4) \AA, b=11.8278(5) \AA, c=17.8730(7) \AA, \alpha=72.7960(10)^{\circ}$, $\beta=83.3820(10)^{\circ}, \quad \gamma=67.1650(10) \underline{o}, \quad Z=2, \quad R_{1}=0.0377, \quad w R_{2}=0.0746 ;$ for $2: \mathrm{C}_{33} \mathrm{H}_{37} \mathrm{LaO}_{14}, \quad$ triclinic, $P-1, \quad a=8.7174(5) \AA$, $b=9.9377(5) \AA, c=21.153(2) \AA, \alpha=81.145(2)^{\circ}, \beta=87.591(2)^{\circ}, \gamma=67.345(5)^{\circ}, Z=2, R_{1}=0.0869$, w $R_{2}=0.220$. 1 is a rare example of the alternative chain constructed by syn-syn and anti-syn coordination mode of carboxylato ligand arranged along the chain alternatively. La(III) ions in 2 are linked by two $\eta^{3}-\mathrm{O}$ bridges and four bridges (two $\eta^{2}-\mathrm{O}$ and two $\eta^{3}-\mathrm{O}$ ) alternatively. Both of the linear coordination polymers grow into two- and three-dimensional networks by packing through extending hydrogen-bond network directed by ligands.
\end{abstract}

(C) 2006 Elsevier Inc. All rights reserved.

Keywords: Lanthanum complex; Hydrogen bonding network; Alternative chain; Acrylic acid

\section{Introduction}

Inorganic crystal engineering is a rapidly growing branch of crystal engineering, which uses coordination-covalent bonds combined with hydrogen bond and other intermolecular interactions to create $1 \mathrm{D}, 2 \mathrm{D}$ and 3D network in crystalline solids [1-3]. The reason is that the versatile coordination geometries provided by the metal ions propagate many kinds of topologies of coordination frameworks. Using ligands with peripheral hydrogenbonding substitutes in coordination complexes is a strategy to build up hydrogen-bonding framework [4]. The coordination chemistry of lanthanide complexes is rich in diversity because of the high coordination numbers (normally $6-10$ ), the origins and validity of the lanthanide

\footnotetext{
*Corresponding author. Department of Chemistry, Beijing Institute of Technology, Beijing 100081, PR China. Fax: +861082575113.

E-mail address: lihui@bit.edu.cn (H. Li).
}

contraction and the exhibited unusual structures and properties [5-8]. Lanthanide complexes have potential applications in biochemistry [9-11] and material science [12-14]. However, the research about the crystal engineering of lanthanide complexes is limited compared with transition metal ions. Lanthanide coordination polymers containing the carboxylato ligands have been the subject of particular interest not only because of their fascinating architectures but also due to their advantageous properties, such as the optical activity and thermal stability. Acrylic acids ligands are new kinds of carboxylato ligand with their most diverse coordination modes [15]. They coordinated with $\mathrm{La}(\mathrm{III})$ ions to form $1 \mathrm{D}$ coordination polymers and have been used in conjunction with these polymers based on their hydrogen bonding substitute. To extend this study, another two kinds of derivatives of acrylic acids, $\alpha$-cyano4-hydroxycinnamic acid $\left(L^{1}\right)$ and trans-3-(4-methyl-benzoyl)-acrylic acid $\left(L^{2}\right)$, were chosen. The structural skeletons of the two ligands are shown in Scheme 1. Both 


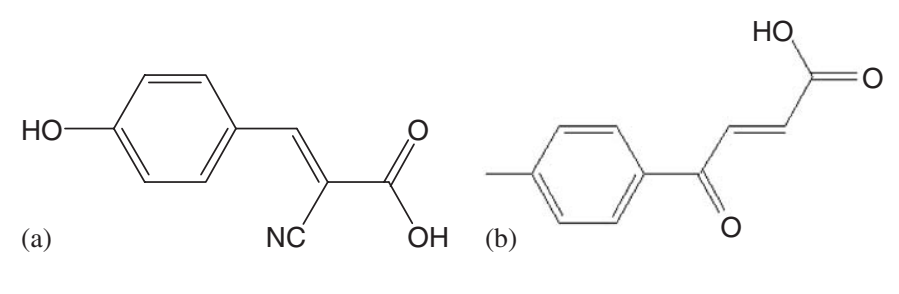

Scheme 1. Structural skeleton of $L^{1}$ (a) and $L^{2}$ (b) ligands.

of them included the hydrogen-bonding substitutes, cyano, hydroxylato in $L^{1}$ and carbonyl in $L^{2}$. Here, the synthesis, crystal structure and some properties of $\left[\mathrm{La}\left(L^{1}\right)_{3}\right.$ $\left.\left(\mathrm{CH}_{3} \mathrm{OH}\right)\left(\mathrm{H}_{2} \mathrm{O}\right)_{2}\right] \cdot 5 \mathrm{H}_{2} \mathrm{O}$ (1) and $\left[\mathrm{La}\left(L^{2}\right)_{3}\left(\mathrm{H}_{2} \mathrm{O}\right)_{2}\right] \cdot 3 \mathrm{H}_{2} \mathrm{O}$ (2) are studied.

\section{Experimental}

\subsection{Materials and methods}

$\mathrm{La}\left(\mathrm{NO}_{3}\right)_{3} \cdot 6 \mathrm{H}_{2} \mathrm{O}$ was purchased from Aldrich. $\alpha$-Cyano4-hydroxycinnamic acid and trans-3-(4-methyl-benzoyl)acrylic acid were purchased from Fluka. All chemicals are used without further purification. Two complexes were confirmed by CHN analysis, IR spectroscopy and X-ray single-crystal diffraction analysis. The elemental analyses were formed on the Pinker-Elmer 2400 Element analyzer. FT-IR spectra were recorded on a Nicolet Fourier Transform IR, MAGNA-IR 500 spectrometer in the range of $500-4000 \mathrm{~cm}^{-1}$ using $\mathrm{KBr}$ disc technique. Thermogravimetric analyses were carried out in Perkin-Elmer spectrometer from the starting temperature $30.0-494.0^{\circ} \mathrm{C}$ in dynamic nitrogen atmosphere with a rate of $5.0^{\circ} \mathrm{C}$.

\subsection{Synthesis of $\left[\mathrm{La}\left(\mathrm{L}^{1}\right)_{3}\left(\mathrm{CH}_{3} \mathrm{OH}\right)\left(\mathrm{H}_{2} \mathrm{O}\right)_{2}\right] \cdot 5 \mathrm{H}_{2} \mathrm{O}$ (1)}

$\left[\mathrm{La}\left(\mathrm{L}^{1}\right)_{3}\left(\mathrm{CH}_{3} \mathrm{OH}\right)\left(\mathrm{H}_{2} \mathrm{O}\right)_{2}\right] \cdot 5 \mathrm{H}_{2} \mathrm{O}$ (1): Solution of $\mathrm{La}$ $\left(\mathrm{NO}_{3}\right)_{3} \cdot 6 \mathrm{H}_{2} \mathrm{O}(50.00 \mathrm{mg}, 0.12 \mathrm{mmol})$ in $10 \mathrm{~mL} \mathrm{CH} \mathrm{CH}_{3} \mathrm{OH}$ was added with a solution of $\alpha$-cyano-4-hydroxycinnamic acid $(68.82 \mathrm{mg}, 0.36 \mathrm{mmol})$ and $\mathrm{NaOH}(14.40 \mathrm{mg}, 0.36 \mathrm{mmol})$ in $10 \mathrm{~mL}$ water solution. After stirring for $2 \mathrm{~h}$, the reaction solution was filtrated. Then, the filtration was diffused by diethyl ether. Colorless needle single crystals suitable for single crystal X-ray diffraction are obtained after 10 days. Yield: $126.30 \mathrm{mg}, 73.30 \%$. Elemental anal. found: C, 43.11; $\mathrm{H}, 4.26 ; \mathrm{N}, 4.85 \%$. Calcd. for $\mathrm{C}_{31} \mathrm{H}_{36} \mathrm{LaN}_{3} \mathrm{O}_{17}: \mathrm{C}, 43.21 ; \mathrm{H}$, 4.21; N, 4.88\%. IR ( $\left.\mathrm{KBr}, \mathrm{cm}^{-1}\right): 3390.8\left(\mathrm{~m}, v_{\mathrm{HO}-\mathrm{H}}\right), 3027.7$ $\left(\mathrm{m}, v_{\mathrm{C}-\mathrm{H}}\right), 2962.0\left(\mathrm{w}, v_{\mathrm{as}(\mathrm{CH} 2)}\right), 1641.4,1562.7\left(\mathrm{vs}, v_{\mathrm{as}\left(\mathrm{COO}^{-}\right)}\right)$, 1470.6, $1424.3(\mathrm{~s}), 735.0,695.6(\mathrm{w})$.

\subsection{Synthesis of $\left[\mathrm{La}\left(\mathrm{L}^{2}\right)_{3}\left(\mathrm{H}_{2} \mathrm{O}\right)_{2}\right] \cdot 3 \mathrm{H}_{2} \mathrm{O}(\mathbf{2})$}

Solution of $\mathrm{La}\left(\mathrm{NO}_{3}\right)_{3} \cdot 6 \mathrm{H}_{2} \mathrm{O}(50.00 \mathrm{mg}, 0.12 \mathrm{mmol})$ in $10 \mathrm{~mL}$ water was added to a solution of trans-3-(4-methylbenzoyl)-acrylic acid $(68.47 \mathrm{mg}, 0.36 \mathrm{mmol})$ and $\mathrm{NaOH}$
$(14.40 \mathrm{mg}, 0.36 \mathrm{mmol})$ in $10 \mathrm{~mL}$ water solution. After stirring for an hour, the reaction solution was filtered. Colorless needle single crystals suitable for single crystal X-ray diffraction are obtained after 7 days by slow evaporation. Yield: $52.30 \mathrm{mg}, 65.66 \%$. Elemental anal. found: C, 49.71; H, 4.69; N, 0.00\%. Calcd. for $\mathrm{C}_{33} \mathrm{H}_{37} \mathrm{LaO}_{14}:: \mathrm{C}$, 49.76; H, 4.68; N, 0.00\%. IR ( KBr, $\left.\mathrm{cm}^{-1}\right): 3400.8\left(\mathrm{~m}, v_{\mathrm{HO}-\mathrm{H}}\right)$, $3031.7\left(\mathrm{~m}, v_{\mathrm{C}-\mathrm{H}}\right), 2958.6\left(\mathrm{w}, v_{\mathrm{as}(\mathrm{CH} 2)}\right), 1640.5,1560.3$ (vs), 1467.8, $1423.6(\mathrm{~s}), 735.7,695.6(\mathrm{w})$.

\subsection{Crystal structure determination}

Single-crystal of complex 1 with dimensions $0.80 \times$ $0.05 \times 0.01$ and complex 2 with dimensions $0.40 \times 0.02 \times$ 0.01 were carefully selected and mounted to a thin glass fiber. X-ray diffraction data were collected on Bruker SMART1000 CCD area detector for $\mathbf{1}$ with graphite monochromated molybdenum $K \alpha(\lambda=0.71073 \AA)$ radiation at a temperature of $295 \pm 2 \mathrm{~K}$ and on Enraf Nonius Kappa CCD area detector for $\mathbf{2}$ with graphite monochromated molybdenum $K \alpha(\lambda=0.71073 \AA)$ radiation at a temperature of $120 \pm 2 \mathrm{~K}$. Unit-cell parameters were determined from automatic centering of 25 reflections and refined using the least-squares method. The diffraction data were corrected for Lorentz and polarization effects, and absorption (empirically from $\Psi$ scan data). No crystals showed significant decay. No extinction correction was necessary for all complexes. All structures were solved by direct methods [16] and refined using full-matrix leastsquares techniques on $F^{2}$ [17]. All non-hydrogen atoms were refined anisotropically. Hydrogen atoms are located geometrically and refined by mixed methods. Crystallographic data of $\mathbf{1}$ and $\mathbf{2}$ are given in Table 1. Selected bond distances and angles for $\mathbf{1}$ and $\mathbf{2}$ are given in Tables 2 and 3 , respectively.

\section{Results and discussion}

\subsection{Synthesis}

In the synthesis of complexes $\mathbf{1}$ and $\mathbf{2}, \mathrm{pH}$ value is controlled by adding $\mathrm{NaOH}$ water solution. The title compounds are obtained at the $\mathrm{pH}$ value around 9. At low $\mathrm{pH}$, the main products are the dinuclear complexes with more coordinated water molecules. At high $\mathrm{pH}$, the polynuclear complexes with hydroxyl bridge ligand are observed. Importantly, no good quantity single crystal structure can be obtained in the reaction conditions with low or high $\mathrm{pH}$ values. We also noted that the counter anions are also the key factor in growing single crystals. Except for the lanthanide nitrate compounds, the other kinds of lanthanide salts are unsuccessful in preparing good single crystals of products in the system. Finally, the solvents in which the ligands and lanthanide compounds have suitable solubility are limited. 
Table 1

Crystallographic data and structure refinements for complexes $\mathbf{1}$ and $\mathbf{2}$

\begin{tabular}{|c|c|c|}
\hline & 1 & 2 \\
\hline M & 861.54 & 796.54 \\
\hline Space group & $P-1$ & $P-1$ \\
\hline$c(\AA)$ & $17.8730(7)$ & $21.153(2)$ \\
\hline$\alpha$ (deg.) & $72.7960(10)$ & $81.145(2)$ \\
\hline$\beta$ (deg.) & $83.3820(10)$ & $87.591(2)$ \\
\hline$\gamma($ deg.) & $67.1650(10)$ & $67.345(5)$ \\
\hline Volume $\left(\AA^{3}\right)$ & $1829.10(13)$ & $1670.2(2)$ \\
\hline$Z$ & 2 & 2 \\
\hline$\rho$ (calc.) $\left(\mathrm{g} \mathrm{cm}^{-3}\right)$ & 1.564 & 1.583 \\
\hline
\end{tabular}

Table 2

Selected bond lengths and bond angles for complex 1

\begin{tabular}{lrlr}
\hline $\mathrm{La}-\mathrm{O}(7)$ & $2.443(2)$ & $\mathrm{La}-\mathrm{O}(8)$ & $2.462(2)$ \\
$\mathrm{La}-\mathrm{O}(5)$ & $2.482(3)$ & $\mathrm{La}-\mathrm{O}(4)$ & $2.492(3)$ \\
$\mathrm{La}-\mathrm{O}(1)$ & $2.516(2)$ & $\mathrm{La}-\mathrm{O}(11)$ & $2.522(3)$ \\
$\mathrm{La}-\mathrm{O}(10)$ & $2.581(3)$ & $\mathrm{La}-\mathrm{O}(12)$ & $2.652(3)$ \\
$\mathrm{N}(3)-\mathrm{C}(23)$ & $1.139(5)$ & $\mathrm{N}(2)-\mathrm{C}(13)$ & $1.142(5)$ \\
$\mathrm{N}(1)-\mathrm{C}(3)$ & $1.134(5)$ & $\mathrm{O}(2)-\mathrm{C}(1)$ & $1.240(5)$ \\
$\mathrm{O}(1)-\mathrm{C}(1)$ & $1.273(4)$ & $\mathrm{O}(4)-\mathrm{C}(11)$ & $1.248(4)$ \\
$\mathrm{O}(3)-\mathrm{C}(8)$ & $1.362(5)$ & $\mathrm{O}(6)-\mathrm{C}(18)$ & $1.365(5)$ \\
$\mathrm{O}(7)-\mathrm{C}(21)$ & $1.247(4)$ & $\mathrm{O}(9)-\mathrm{C}(28)$ & $1.361(5)$ \\
$\mathrm{O}(7)-\mathrm{La}(1)-\mathrm{O}(8)$ & $93.46(9)$ & $\mathrm{O}(5)-\mathrm{La}(1)-\mathrm{O}(7)$ & $92.42(9)$ \\
$\mathrm{O}(8)-\mathrm{La}(1)-\mathrm{O}(5)$ & $151.14(9)$ & $\mathrm{O}(7)-\mathrm{La}(1)-\mathrm{O}(4)$ & $138.45(9)$ \\
$\mathrm{O}(8)-\mathrm{La}(1)-\mathrm{O}(4)$ & $79.24(9)$ & $\mathrm{O}(5)-\mathrm{La}(1)-\mathrm{O}(4)$ & $113.56(9)$ \\
$\mathrm{C}(21)-\mathrm{O}(7)-\mathrm{La}(1)$ & $146.2(2)$ & $\mathrm{C}(21) \# 2-\mathrm{O}(8)-\mathrm{La}(1)$ & $144.0(2)$ \\
$\mathrm{C}(11)-\mathrm{O}(4)-\mathrm{La}(1)$ & $111.7(2)$ & $\mathrm{C}(11) \# 1-\mathrm{O}(5)-\mathrm{La}(1)$ & $169.1(2)$ \\
\hline
\end{tabular}

Symmetry transformations used to generate equivalent atoms: \#1 $-x-2$, $-y+4,-z ; \# 2-x-3,-y+4,-z$.

\subsection{Crystal structure of \\ $\left[\mathrm{La}\left(\mathrm{L}^{1}\right)_{3}\left(\mathrm{CH}_{3} \mathrm{OH}\right)\left(\mathrm{H}_{2} \mathrm{O}\right)_{2}\right] \cdot 5 \mathrm{H}_{2} \mathrm{O}(\mathbf{1})$}

Many attempts have been made to control molecular arrangements in crystals by simultaneous use of coordination bonds of metal ions and complementary intermolecular hydrogen bonding [18-20]. Both the complexes in this work are designed based on this idea.

The single crystal X-ray diffraction analysis reveals that the complex $\mathbf{1}$ is a one-dimensional chain structure. Each $\mathrm{La}(\mathrm{III})$ ion in $\left[\mathrm{La}\left(L^{1}\right)_{3}\left(\mathrm{CH}_{3} \mathrm{OH}\right)\left(\mathrm{H}_{2} \mathrm{O}\right)_{2}\right] \cdot 5 \mathrm{H}_{2} \mathrm{O}$ is eightcoordinated: to five $L^{1}$ ligands, to two water molecules and to one methanol molecule. Five water molecules are outside the coordination sphere. The coordination environment of $\mathrm{La}(\mathrm{III})$ is shown in Fig. 1. The coordination
Table 3

Selected bond lengths and bond angles for complex 2

\begin{tabular}{lclr}
\hline $\mathrm{La}-\mathrm{O}(2)$ & $2.594(7)$ & $\mathrm{La}-\mathrm{O}(7) \# 2$ & $2.744(7)$ \\
$\mathrm{La}-\mathrm{O}(3)$ & $2.628(7)$ & $\mathrm{La}-\mathrm{O}(5)$ & $2.495(6)$ \\
$\mathrm{La}-\mathrm{O}(6)$ & $2.599(7)$ & $\mathrm{La}-\mathrm{O}(4)$ & $2.606(6)$ \\
$\mathrm{La}-\mathrm{O}(7)$ & $2.510(6)$ & $\mathrm{La}-\mathrm{O}(8)$ & $2.450(6)$ \\
$\mathrm{La}-\mathrm{O}(10)$ & $2.590(7)$ & $\mathrm{La}-\mathrm{O}(5) \# 1$ & $2.839(7)$ \\
$\mathrm{O}(2)-\mathrm{C}(20)$ & $1.266(11)$ & $\mathrm{O}(5)-\mathrm{C}(20) \# 1$ & $1.255(11)$ \\
$\mathrm{O}(6)-\mathrm{C}(30) \# 1$ & $1.284(11)$ & $\mathrm{O}(7)-\mathrm{C}(10) \# 2$ & $1.283(12)$ \\
$\mathrm{O}(8)-\mathrm{C}(30)$ & $1.258(11)$ & $\mathrm{O}(10)-\mathrm{C}(10)$ & $1.241(12)$ \\
$\mathrm{O}(11)-\mathrm{C}(13)$ & $1.192(17)$ & $\mathrm{O}(22)-\mathrm{C}(23)$ & $1.219(13)$ \\
$\mathrm{La}-\mathrm{O}(5)-\mathrm{La} \# 1$ & $107.5(2)$ & $\mathrm{La}-\mathrm{O}(7)-\mathrm{La} \# 2$ & $118.0(2)$ \\
$\mathrm{O}(7) \# 2-\mathrm{La}-\mathrm{O}(5) \# 1$ & $167.76(18)$ & $\mathrm{O}(7)-\mathrm{La}-\mathrm{O}(5)$ & $145.4(2)$ \\
$\mathrm{O}(7)-\mathrm{La}-\mathrm{O}(5) \# 1$ & $110.1(2)$ & $\mathrm{O}(5)-\mathrm{La}-\mathrm{O}(6)$ & $80.4(2)$ \\
$\mathrm{C}(30)-\mathrm{O}(8)-\mathrm{La}$ & $140.3(6)$ & $\mathrm{C} 30 \# 1-\mathrm{O}(6)-\mathrm{La}$ & $133.3(6)$ \\
$\mathrm{O}(8)-\mathrm{La}-\mathrm{O}(5) \# 1$ & $68.2(2)$ & $\mathrm{O}(5)-\mathrm{La}-\mathrm{O}(5) \# 1$ & $72.5(2)$ \\
$\mathrm{O}(7)-\mathrm{La}-\mathrm{O}(7) \# 2$ & $62.0(2)$ & $\mathrm{O}(10)-\mathrm{La}-\mathrm{O}(7) \# 2$ & $48.4(2)$ \\
\hline
\end{tabular}

Symmetry transformations used to generate equivalent atoms: $\# 1-x+2$, $-y+2,-z+1 ; \# 2-x+1,-y+2,-z+1$.

geometry of La (III) ion in $\mathbf{1}$ can be considered as a distorted dodecahedron. All $L^{1}$ ligands coordinated with La (III) ions are in monodentate mode. Four of the five $L^{1}$ ligands bridge the adjacent La (III) ions into 1D chain using $\eta^{2}-\mathrm{O}$ carboxylato bridge modes (Fig. 2). Between $\mathrm{La}(1)$ and $\mathrm{La}(1 \mathrm{~A}), \eta^{2}-\mathrm{O}$ bridge is in syn-syn configuration $(\mathrm{C}(21)$ $\mathrm{O}(7)-\mathrm{La}(1) 146.2(2)^{\circ}$; C(21)\#2-O(8)-La(1) 144.0(2) $)^{\circ}$, which is very similar to that in (E)-3-(2-hydroxyl-phenyl)-acrylic acid La(III) complex [15]. Distance between $\mathrm{La}(1)$ and $\mathrm{La}(1 \mathrm{~A})$ is $5.317 \AA$. The $\eta^{2}-\mathrm{O}$ bridge between $\mathrm{La}(1 \mathrm{~A})$ and $\mathrm{La}(1 \mathrm{~B})$ is in anti-syn configuration $(\mathrm{C}(11)-\mathrm{O}(4)-\mathrm{La}(1)$ 111.7(2); $\left.\mathrm{C}(11) \# 1-\mathrm{O}(5)-\mathrm{La}(1) \quad 169.1(2)^{\circ}\right)$ with $\mathrm{La}(1 \mathrm{~A})-$ $\mathrm{La}(1 \mathrm{~B})$ distance of $4.643 \AA$. It is a rare example of alternative chain constructed by syn-syn and anti-syn coordination mode of $\alpha$-cyano-4-hydroxycinnamic acid. 


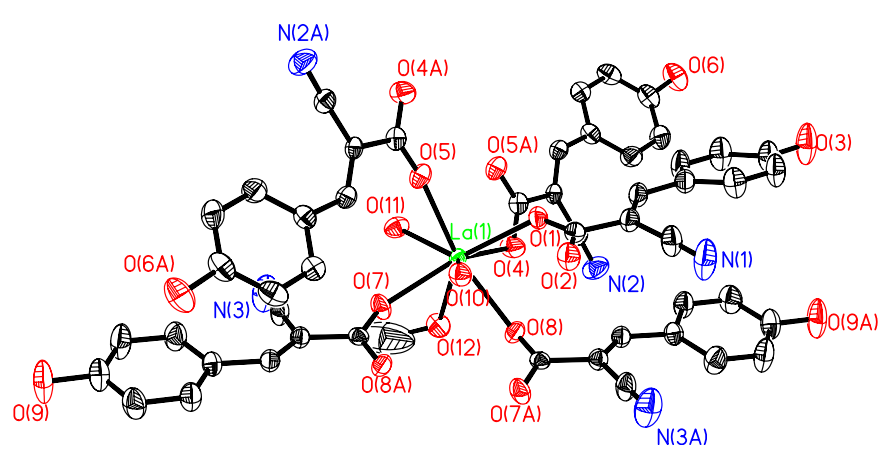

Fig. 1. ORTEP drawing of the coordination geometry of the $\mathrm{La}$ (III) ion in complex 1: $\left[\mathrm{La}\left(L^{1}\right)_{3}\left(\mathrm{CH}_{3} \mathrm{OH}\right)\left(\mathrm{H}_{2} \mathrm{O}\right)_{2}\right] \cdot 5 \mathrm{H}_{2} \mathrm{O}(50 \%$ thermal ellipsoids). Hydrogen atoms and solvent molecules are omitted for clarity.

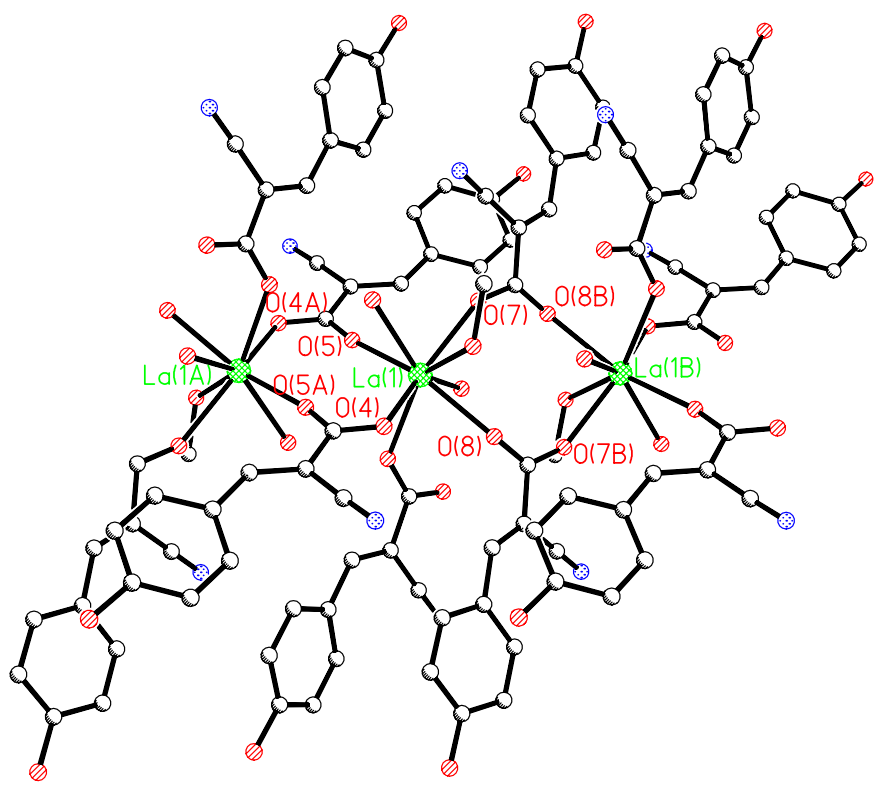

Fig. 2. 1D chain structure of complex 1: $\mathrm{La}(1 \mathrm{~A})-\mathrm{La}(1)=4.643 \AA$; $\mathrm{La}(1)-\mathrm{La}(1 \mathrm{~B})=5.317 \AA$.

The 1D chains of $\mathbf{1}$ are linked by intermolecular hydrogen bonding to form 3D open framework in crystal lattice. The types of $\mathrm{H}$ bonding are $\mathrm{O}-\mathrm{H} \cdots \mathrm{O}$ and $\mathrm{C} \equiv \mathrm{N} \cdots \mathrm{H}$. Solvent water molecules act as both donor and acceptor of hydrogen atoms.

The cyano group in $L^{1}$ ligand forms $\mathrm{H}$ bonding with the coordinated methanol molecules of adjacent chain in $2 \mathrm{D}$ direction $(\mathrm{N}(2) \cdots \mathrm{H}(12 \mathrm{AB})-\mathrm{O}(12 \mathrm{~A}) ; \quad 2.203 \AA, \quad 2.932 \AA$, $138.0^{\circ}$ ) (Fig. 3a). The cyano group in another $L^{1}$ ligand coordinated to the same La (III) ion forms $\mathrm{H}$ bonding with hydroxylato group of the neighbor chain along the three dimensions $(\mathrm{N}(1) \cdots \mathrm{H}(3 \mathrm{AB})-\mathrm{O}(3 \mathrm{~B}) ; 1.983 \AA, 2.799 \AA$, $\left.173.1^{\circ}\right)$. There are one-dimensional channels viewed down from $a$-axis in the crystal lattice (Fig. $3 b$ ). The details of $\mathrm{H}$ bonding in 2D and 3D are shown in Fig. 3c. The solvent water molecules are all sited in these channels.

\subsection{Crystal structure of $\left[\mathrm{La}\left(\mathrm{L}^{2}\right)_{3}\left(\mathrm{H}_{2} \mathrm{O}\right)_{2}\right] \cdot 3 \mathrm{H}_{2} \mathrm{O}$ (2)}

The coordination number of $\mathrm{La}(\mathrm{III})$ ion is 10 in $\mathbf{2}$ instead of eight in 1. There are five ligands $\left(L^{2}\right)$ and two coordinated water molecules coordinated to $\mathrm{La}(\mathrm{III})$ ion in complex 2. Two ligands are coordinated with La (III) ion in bidentate mode and the left three are in monodentate mode (Fig. 4). In 1D chain, there are four bridges, two $\eta^{3}-\mathrm{O}$ bridges and two $\eta^{2}-\mathrm{O}$ bridges between $\mathrm{La}$ and $\mathrm{La}(\mathrm{B})$ with a $\mathrm{La}-\mathrm{La}$ (B) distance of $4.306 \AA$ (Fig. 5). The $\eta^{2}-\mathrm{O}$ bridge is in syn-syn configuration $(\mathrm{C}(30)-\mathrm{O}(8)-\mathrm{La}$, $\left.140.3(6)^{\circ} ; \mathrm{C}(30 \mathrm{~B})-\mathrm{O}(6)-\mathrm{La}, 133.3(6)^{\circ}\right)$. There are only two $\eta^{3}-\mathrm{O}$ bridges to link $\mathrm{La}$ and $\mathrm{La}(\mathrm{A})$ with $\mathrm{La}-\mathrm{La}(\mathrm{A})$ distance of $4.506 \AA$. Therefore, complex 2 is an alternative chain again, which is constructed by the different number of carboxylato bridge ligands between the adjacent $\mathrm{La}(\mathrm{III})$ ions. It is very similar to that of La (III) complex with (E)3-(4-hydroxyl-phenyl)-acrylic acids) ligand [15].

Bond lengths of La (III)-O in $\mathbf{1}$ and $\mathbf{2}$ fall in the range $(2.443(2)-2.839(7) \AA)$ that falls in normal scale [15,21-24]. The shortest La (III)-O distance $(2.443 \AA)$ is in $\eta^{2}-\mathrm{O}$ carboxylato bridge and the longest one $(2.839 \AA)$ is in $\eta^{3}-\mathrm{O}$ carboxylato bridge.

The types of $\mathrm{H}$ bonding in $\mathbf{2}$ are $\mathrm{O}-\mathrm{H} \cdots \mathrm{O}$ and $\mathrm{C}=\mathrm{O} \cdots \mathrm{H}$. Both coordinated and solvent water molecules act as not only donor but also acceptor of hydrogen atoms. Different from complex $\mathbf{1}$, all solvent and coordinated water molecules are located in the same layer in $\mathbf{2}$ to form $\mathrm{H}$-bonding framework along the two dimensions. As we expected, the methyl group in the 4-position of $L^{2}$ ligand blocked the hydrogen bonding interaction between the layers. The solvent water molecules have strong H-bonding interactions with the carboxylato oxygen atoms. The distances between these oxygen atoms of $\mathrm{H}$ bonding are ranged in 2.697-2.858 (Fig. 6a). Carbonyl oxygen atoms form non-conventional $\mathrm{H}$ bonding with hydrogen atom in benzene ring $(\mathrm{O}(33) \cdots \mathrm{H}(29 \mathrm{~B}), 2.452 \AA, \mathrm{O}(33) \cdots \mathrm{H}(29 \mathrm{~B})$ $\mathrm{C}(29)\left(\right.$ in benzene), $3.194 \AA, 136.8^{\circ}$ ). There is only van der Walls interaction between the layers along $3 \mathrm{D}$ direction with the distance of the adjacent layers around $5.005 \AA$ (Fig. 6b).

\subsection{IR spectrum}

The IR spectrum of $\mathbf{1}$ shows characteristic bands of carboxylato groups at 1581 and $1412 \mathrm{~cm}^{-1}$. These bands appear at 1639 and $1413 \mathrm{~cm}^{-1}$ in the IR spectrum of 2 . The absence of the characteristic bands around $1700 \mathrm{~cm}^{-1}$ in $\mathbf{1}$ and 2 attributed to the protonated carboxylato groups indicates that their complete deprotonation upon reaction with $\mathrm{La}^{3+}$ in the two compounds, which are in good agreement with their single crystal X-ray diffraction analyses.

\section{Conclusion}

Two linear coordination polymers of lanthanide with the derivatives of acrylic acids, $\alpha$-cyano-4-hydroxycinnamic 


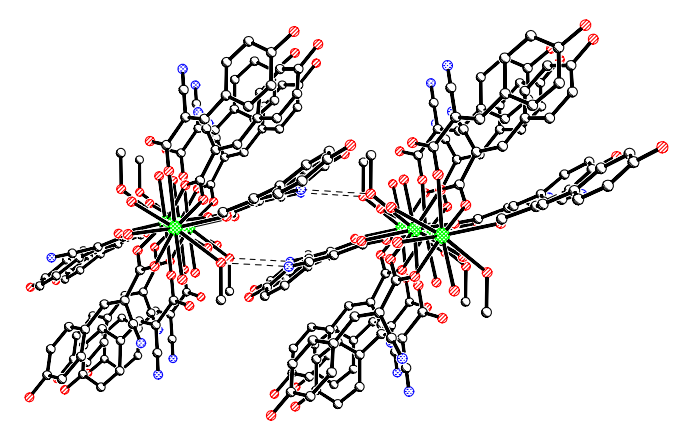

(a)

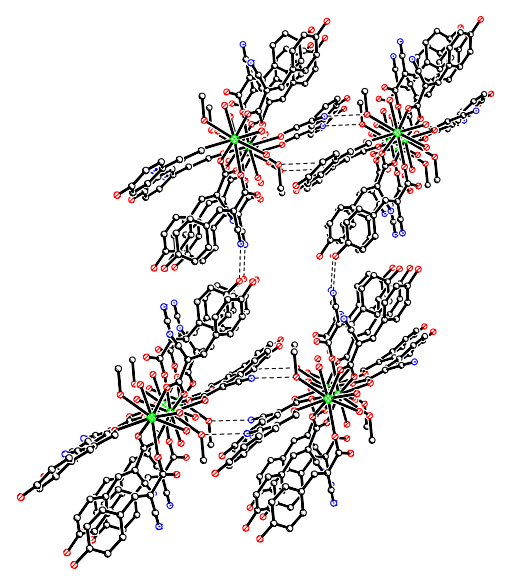

(b)
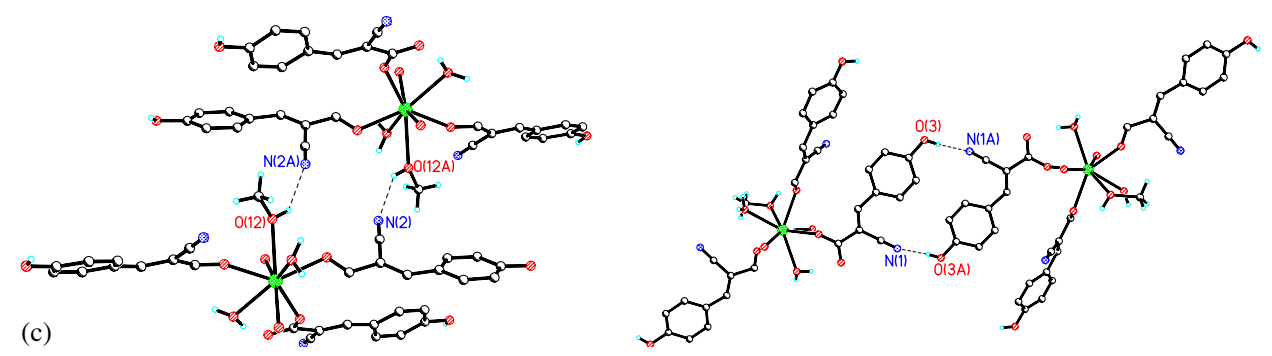

Fig. 3. The H-bonding interactions in 2D (a) and 3D (b) molecular packing in complex 1 (view down from $a$ axis). (c) Detail of the $\mathrm{H}$ bonding in $2 \mathrm{D}$ and 3D for complex 1 .

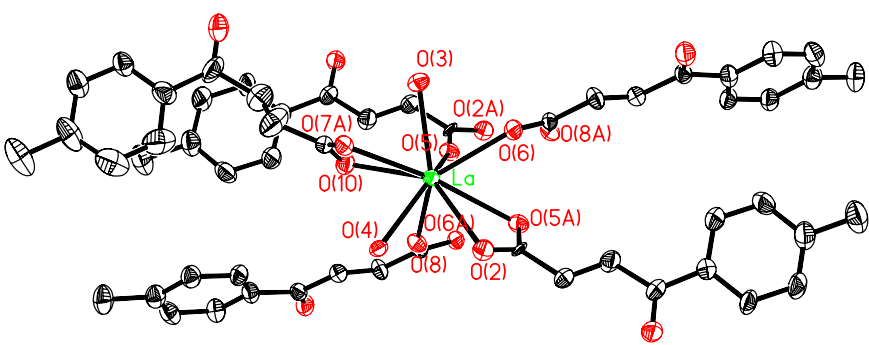

Fig. 4. ORTEP drawing of the coordination geometry of the La(III) ion in complex 2: $\left[\mathrm{La}\left(L^{2}\right)_{3}\left(\mathrm{H}_{2} \mathrm{O}\right)_{2}\right] \cdot 3 \mathrm{H}_{2} \mathrm{O}(50 \%$ thermal ellipsoids). Hydrogen atoms and solvent molecules are omitted for clarity.

acid and trans-3-(4-methyl-benzoyl)-acrylic acid, have been synthesized. The polymer $\mathbf{1}$ and $\mathbf{2}$ grow into a threedimensional and a two-dimensional network by packing through extending hydrogen-bond network from the pregnancy of ligand, respectively. $\mathbf{1}$ is a rare example of an alternative chain constructed by syn-syn and anti-syn coordination mode of carboxylato ligand arranged along the chain alternatively. $\mathbf{2}$ is a two-dimensional extending layer rising from the blocking of the $\mathrm{H}$-bonding functional group of the $L^{2}$ ligand between layers. This work shows that the subtle change of the ligand can direct the significant difference in the solid state of crystalline coordination polymers.

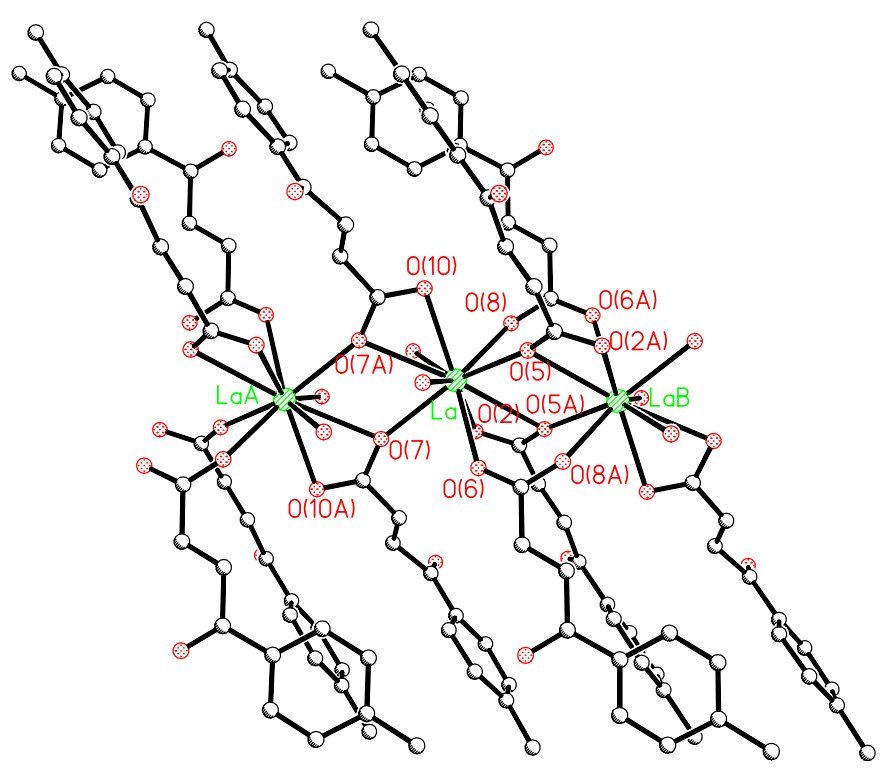

Fig. 5. $1 \mathrm{D}$ chain structure of complex 2: $\mathrm{La}(\mathrm{A})-\mathrm{La}=4.506 \AA$; $\mathrm{La}-\mathrm{La}$ (B) $=4.305 \AA$

\section{Supporting information available}

X-ray crystallographic files in CIF format for the structure determination of compounds $\mathbf{1}$ and $\mathbf{2}$ may be 
(a)

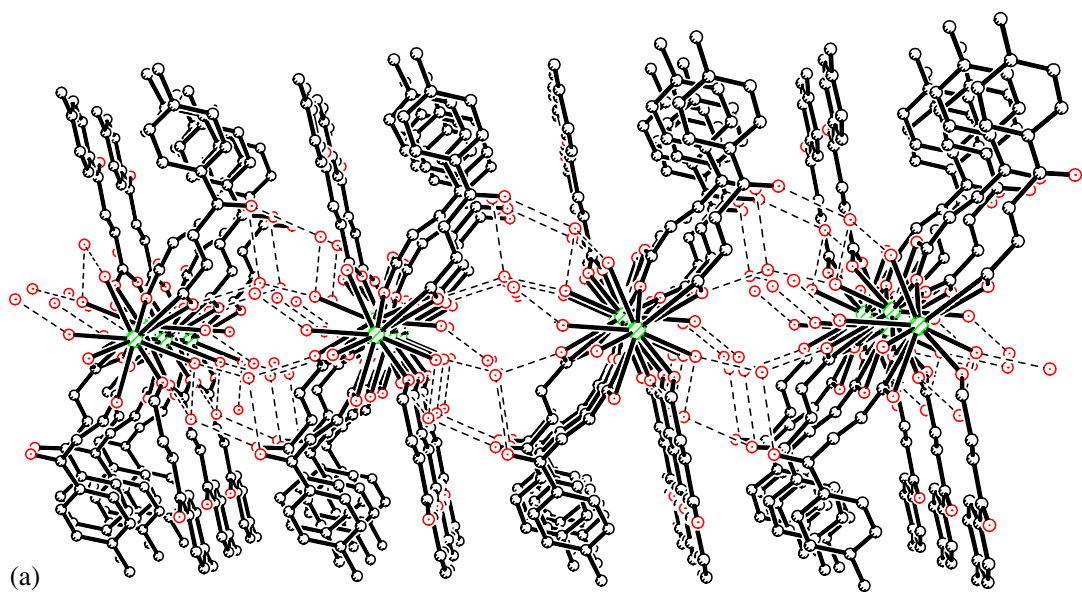

(b)
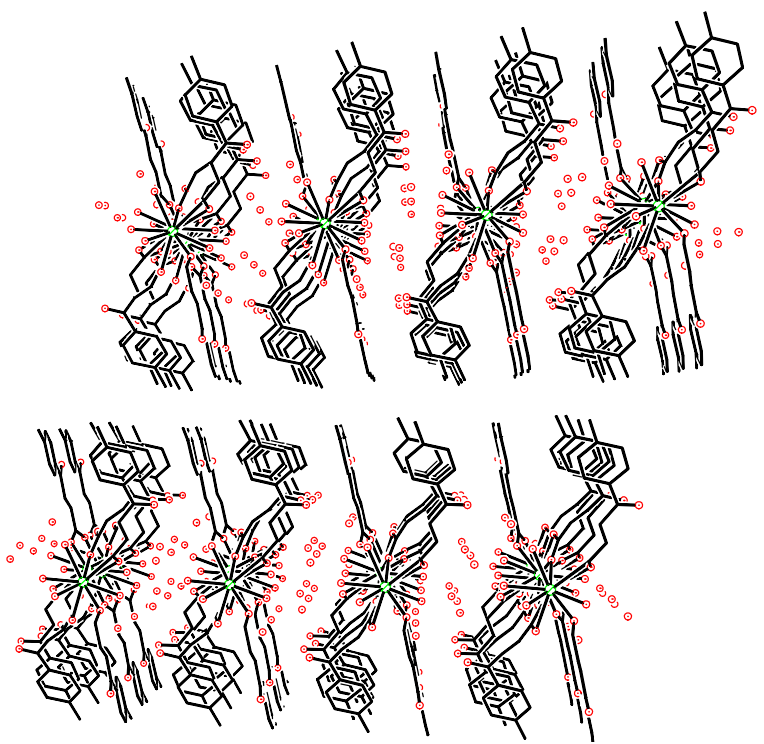

Fig. 6. The H-bonding interactions in 2D (a) and 3D (b) molecular packing in complex 2 (view down from $a$ axis).

obtained free of charge from The Director, CCDC, 12 Union Road, Cambridge, CB2 IEZ, UK (Fax: 441223 336033; e-mail: deposit@ccdc.cam.ac.uk). The CCDC numbers for $\mathbf{1}$ and $\mathbf{2}$ are 257806 and 230998, respectively.

\section{Acknowledgments}

This work was supported by the Natural Science Fund Council of China (NSFC, no. 20571011), the Scientific Research Foundation for the Returned Overseas Chinese Scholars, State Education Ministry of China (LXKYJJ200408) and The University Basic Research Foundation of Beijing Institute of Technology (BITUBF, no. 200507B4202).

\section{References}

[1] B. Moulton, M.J. Zaworotko, Curr. Opin. Solid State Mater. Sci. 6 (2002) 117
[2] S.R. Battern, R. Robson, Amgrew. Vhem. Int. Ed. 37 (1998) 1460.

[3] M. Eddaoudi, D.B. Moler, H.L. Li, B.L. Chen, T.M. Reineke, M. O'Keeffe, O.M. Yaghi, Acc. Chem. Res. 34 (2001) 319.

[4] A.M. Beatty, Coord. Chem. Rev. 246 (2003) 131.

[5] Z. Zheng, R. Wang, Comments Inorg. Chem. 22 (2000) 1 and references cited therein.

[6] B.-L. An, M.-L. Gong, K.-W. Cheah, J.-M. Zhang, K.-F. Li, Chem. Phys. Lett. 385 (2004) 345.

[7] B.-L. An, M.-L. Gong, J.-M. Zhang, J. Mol. Struct. 687 (2004) 1.

[8] H. Sigel, A. Sigel (Eds.), Metal ions in Biological Systems: The Lanthanides and their Inter-Relations with Biosystems, vol. 40, Marcel Dekker, Basel, 2003.

[9] Y. Bretonniere, R. Wietzke, C. Lebrun, M. Mazzanti, J. Pecaut, Inorg. Chem. 39 (2000) 3499.

[10] L. Tei, G. Baum, A.J. Blake, D. Fenske, M. Schroder, Dalton (2000) 2793.

[11] M. Andruh, I. Ramade, E. Codjovi, O. Guillou, O. Kahn, J.C. Trombe, J. Am. Chem. Soc. 115 (1993) 1822.

[12] X.-M. Chen, Y.-Lu. Wu, Y.-Y. Yang, S.M.J. Aubin, D.N. Hendrickson, Inorg. Chem. 37 (1998) 6186.

[13] F.D. Cukiernik, M. Ibn-Elhaj, Z.D. Chaia, J.-C. Marchon, A.-M Anne-Marie, D. Guillon, A. Skoulious, P. Maldivi, Chem. Mater. 10 (1998) 83. 
[14] J. Fang, H. You, J. Chen, J. Lin, D. Ma, Inorg. Chem. 45 (2006) 3701 .

[15] H. Li, C.-W. Hu, J. Solid State Chem. 177 (2004) 4501.

[16] G.M. Sheldrick, SHELXS-97, University of Gottingen, Germany, 1997.

[17] G.M. Sheldrick, SHELXL-97, University of Gottingen, Germany, 1997.

[18] Q.-D. Liu, J.-R. Li, S. Gao, B. Qing Ma, Q.-Z. Zhou, H. Liu, K.B. Yu, Chem. Commun. (2000) 1685.
[19] Y.Q. Zheng, L.-X. Zhou, J.-L. Lin, S.-W. Zhang, Z. Anorg. Allg. Chem. 626 (2000) 1715.

[20] B. Yan, H.D. Womg, Z.D. Chen, Polyhedron 20 (2001) 591.

[21] J.-M. Lehn, Supramolecular Chemistry, VHC, Weinheim, 1995.

[22] G.M. Whitesides, J.P. Mathias, C.T. Seto, Science 254 (1991) 1312.

[23] Tadokoro, K. Nakasuji, Coord. Chem. Rev. 198 (2000) 205.

[24] S. Subramanian, M.J. Zaworotko, Coord. Chem. Rev. 137 (1994) 357. 